\title{
Author's reply: Regarding the editorial by Penttinen and Friede
}

PM Penttinen ${ }^{1}$, MH Friede ${ }^{2}$

1. European Centre for Disease Prevention and Control (ECDC), Stockholm, Sweden

2. Initiative for Vaccine Research (IVR), World Health Organization (WHO), Geneva, Switzerland

Correspondence: Pasi M Penttinen (Pasi.Penttinen@ecdc.europa.eu)

Citation style for this article:

Penttinen PM, Friede MH. Author's reply: Regarding the editorial by Penttinen and Friede. Euro Surveill. 2016;21(40):pii=30367. D0I: http://dx.doi. org/10.2807/1560-7917.ES.2016.21.40.30367

Article submitted on 03 October 2016 / accepted on 06 October 2016 / published on 06 October 2016

To the editor: We thank Fry et al. for their interest in our editorial, in which we sought to lay out the evolving evidence surrounding the effectiveness of live attenuated influenza vaccine (LAIV) in preventing infections with influenza $A\left(\mathrm{H}_{1} \mathrm{~N}_{1}\right)$ pdmog and the potential consequences of a perceived or true lack of effectiveness for childhood immunisation programmes and pandemic preparedness [1]. We appreciate that they meticulously highlight several errors in the Table and provided more accurate data which was not available to us through the original presentations from the United States (US) Advisory Committee on Immunization Practices (ACIP) [2]. All errors were corrected in the original text on 29 September and the more accurate sample sizes and confidence intervals were incorporated as suggested. In our view, these amendments do not change our conclusions. We look forward to the peer-reviewed publication of vaccine effectiveness (VE) studies done in the US as important contributions to the evidence base.

Fry et al. note that the VE estimate for Finland referred to all type $A$ influenza, not specifically to influenza $\mathrm{A}\left(\mathrm{H}_{1} \mathrm{~N}_{1}\right)$ pdmo9. However, it is important to note that only $7 \%$ of subtyped influenza viruses during the 2015/16 season from Finland were influenza $A\left(\mathrm{H}_{3} \mathrm{~N}_{2}\right)$, and almost all of those came from adult patients [3]. Therefore, we assume that the VE estimate against influenza $A$ in Finland accurately reflects the VE against influenza $A\left(\mathrm{H}_{1} \mathrm{~N}_{1}\right)$ pdmog in children.

We note that Fry et al. agree with our final conclusion in that 'It is critical to understand why LAIV did not work as expected against the 2009 pandemic virus in the multivalent formulations' [4]. We suggest that the international scientific collaboration already established between the involved public health agencies under the coordination of the World Health Organization continues at an intensive pace in order to ensure that the scientific community, the public health community, policymakers and manufacturers resolve this critical question..

Conflict of interest

None declared.

Authors' contributions

Both authors contributed equally to conception and writing of this letter.

References

1. Penttinen PM, Friede $M H$. Decreased effectiveness of the influenza $A\left(\mathrm{H}_{1} \mathrm{~N}_{1}\right)$ pdmog strain in live attenuated influenza vaccines: an observational bias or a technical challenge?Euro Surveill. 2016;21(38):30350. DOI: 10.2807/1560-7917. ES.2016.21.38.30350 PMID: 27684999

2. Centers for Disease Control and Prevention (CDC). Advisory Committee on Immunization Practices (ACIP). ACIP meeting information, Presentation slides 22-23 June 2016. [Accessed 27 Sep 2016]. Available from: http://www.cdc.gov/vaccines/acip/ meetings/slides-2016-06.html

3. Terveyden ja hyvinvoinnin laitos (THL) [National Institute for Health and Welfare, Finland]. Influenssakausi Suomessa, viikot 40/2015-20/2016. Seurantaraportti. [Influenza season in Finland, weeks 40/2015-20/2016. Surveillance report]. 2016. Available from: http://www.julkari.fi/bitstream/ handle/10024/130791/URN_ISBN_978-952-302-682-7. pdf?sequence $=1$

4. Fry AM, Flannery B, Olsen SJ, Grohskopf L, Bresee J. Letter to the editor: Regarding the editorial by Penttinen and Friede. Euro Surveill. 2016;21(40):pii=30366. DOI: http://dx.doi.org/ DOI: $10.2807 / 1560-7917 . E S .2016 .21 .40 .30366$

License and copyright

This is an open-access article distributed under the terms of the Creative Commons Attribution (CC BY 4.0) Licence. You may share and adapt the material, but must give appropriate credit to the source, provide a link to the licence, and indicate if changes were made.

This article is copyright of the authors, 2016. 